\section{SCIENCE IN PARIS DURING THE SIEGE}

$I \mathrm{~N}$ a somewhat striking passage in the De Augmentis Scientiarum Francis Bacon contrasts the endurance of monuments of learning with that of those raised by the hand of man. The verses of Homer, he reminds us, have endured formore than twenty centuries, during which time numberless palaces, temples, and cities have disappeared from the face of the earth. Some such reflection as this may have induced the members of the Academie des Sciences of Paris to continue their weekly meetings with perfect regularity during the bombardment. While everything else was turned upside down, while a dynasty was passing away, while sons and brothers were perishing around them, an enemy at their gates, want within their walls, and missiles of war threatening themselves and their household gods, these men continued their usual studies. We are reminded of Archimedes at the siege of Syracuse, save that there we have but one man, while here it is a large body of the intellectual flower of the country. Some of the more active of the members are men who have attained that philosophic calm, which not even the terrors of war can dispel, nothing diverts them from the even tenour of their way-

\section{Si fractus illabatur orbis, \\ Impavidum ferient ruinæ.}

We frequently meet with the names of Dumas, Elie de Beaumont, and Chevreul in the Comptes Rendus published during the siege. The youngest of these men was born in the last year of the last century; they have seen every phase of Parisian life, are men of infinite experience and learning, the very soul of the Academy; they have held office under various Governments, have seen more than one revolution; barricades and street fighting, and the Yarthian cap are no novelty to them; but with all their experience they had never beheld a bombardment of Paris; yet, all honour to them, they did not abate one jot of their Academic work. Perhaps the members may have felt it a relief to have to deal with immutable and indestructible facts, while everything around them was so mutable and perishing. Perhaps they remembered a saying of one of their countrymen :-" L'homme n'a pas de self-critérium. L'indestructibilité du fait est le critérium unique, infaillible, absolu, multiple, un, présent dans tous les ordres des connaissances."

The papers read before the Academy during the period of ihe siege relate for the most part to matters connected with war and to the food resources of a besieged city. M. Payen writes on hippophagy, M. Frémy on the use of osseine as food, M. Riche on the use of black puddings of ox-blood. In the Revue des Cours Scientifiques we also find some important papers by M. Bouchardat on the food supply of Paris, and a paper by the same author on the sanitary condition of the city during the siege, and during the same months of the preceding year. M. Berthelot has contributed some important papers on the force of various explosive substances, both solid, liquid, and gaseous. These papers are well worthy the attention of our wat authorities. There is also a paper on dynamite, by $M$. Champion, and on the ignition of gunpowder at a distance by means of electricity. The subject of balloons and ballooning, of course, engages a good deal of discussion. M. Marey contributes several important papers on the motions of birds during flight, accompanied by graphic representations of them, registered somewhat after the manner of the vibrations of a tuning fork, and shown by sinuous lines. The diagram representing the vertical oscillations of a wild duck during fight is very striking. Beyond these papers there is nothing of much importance.

Here, for example, are the principal papers of one number (December 5 th) taken at random:-

* Phicosophze Méthodzque, par J. de Strada, a work too little known in this country.
M. Milne-Edwards discusses the nutritive value of organic substances contained in bones, and the proper rations for sustaining the human body in a perfect state of health; M. Chevreul makes observations upon $M$. Frémy's paper on the use of osseine as food ; M. Gazeau details various experiments on the nutritive properties of cocoa leaves ; M. Montier treats of the specific heat of gases under constant volume; $M$. Riche of the preparation of osseine and gelatine; and M. Castelhaz of the refining of crude tallow.

The future historian of science will wonder when he reads in the Comptes Rendus for January 9, 1871 :-

M. Chevreul donne Iecture à l'Académie de la déclaration suivante :

"Le jardin des plantes médicinales, fondé à Paris par édit du Roi Louis XIII. la date du mois de janvier, 1626.

"Devenu le Muséum d'Histoire naturelle par décret de la Convention du Io de juin 1793 .

" "Fut bombardé,

"Sous le règne de Guillaume Ier roi de Prusse, Comte de Bismark chancelier

"Pal l'armée Prussienne, dans la nuit du 8 au 9 de janvier, $187 \mathrm{I}$.

"Jusque-là, il avait été respecté de tous les partis et de tous les pouvoirs nationaux et étrangers. "E. Chevreul, Directerur."

He will grieve when he reads " $M$. Le Président annonce à l'Académie la douloureuse nouvelle, malheureusement très-probable, de la mort du . . . occurring too often in what should be only a record of the living and of their work. So we grieve: and yet more when we see the intellectual resources and energies of a great country paralysed, and the whole current of its active thought diverted no man knows whither; while its schools and colleges are empty, and many of those who should be in them have been killed untimely to satisfy the necessities of war.

G. F. RODWELL

\section{AMERICAN NOTES}

WE learn from Harper's Weekly that the fourth volume of the "Report of the Geological Survey of Illinois," which has been in progress for several years past, under the direction of Prof. A. H. Worthen, has just been published. Like its predecessors, it is a handsome book, well illustrated, and containing much important matter relating to the geology and physical features of the State. This volume is occupied by a detailed account from assistants in the survey in regard to particular counties in the State, followed by systematic papers-one upon the fossil fishes by Prof. J. S. Newberry and Prof. Worthen, and the other upon fossil plants by Prof. Lesquereaux, illustrated by a number of well engraved steel plates. The economical value of such a survey to the State, conducted with the spirit and efficiency which have marked Prof. Worthen's administration from the beginning is exceedingly great, and cannot be estimated in dollars and cents. Not merely does it furnish a fund of information to the residents of Illinois, but it supplies an official guarantee to others in regard to the resources of the State which could not be obtained in any other way.-We have, in a previous article, referred to some interesting speculations by Prof. Shaler, of Cambridge, upon the formation of the New England coast; and we find in the proceedings of the Boston Society of Natural History for February last some additional remarks by him on the same subject. He considers that the Chesapeake and Delaware bays, like many of the deep gorges in Switzerland and elsewhere, were formed by the action of ice, and that the existence of Cape Hatteras is due to the uplifting of the rocks on which Richmond is situated. The sand-bars on the coast he believes to have been formed by the material dug out of the Delaware and Chesapeake bays by this ice action, and worked southward by the united force of the floods and currents. He finds that, after we pass these 